\title{
Radiological Examinations of Inferior Turbinate in Patients with or without Deviated Nasal Septum by Using Computed Tomography
}

\author{
Do-Yang Park, Min Ho Noh, Seung Bum Park, Won Woo Ban, \\ Kong Geun Bae, Bo Sung Kang, and Byoung-Joon Baek \\ Department of Otolaryngology-Head and Neck Surgery, Cheonan Hospital, Soonchunhyang University College of Medicine, \\ Cheonan, Korea
}

\section{전산화단층촬영의 분석을 통한 비중격 만곡증 유무에 따른 하비갑개 형태변화 연구}

박도양 · 노민호 · 박승범 · 반원우 · 배공근 · 강보성 · 백병준

순천향대학교 의과대학 천안병원 이비인후과학교실

Received August 18, 2015

Revised October 20,2015

Accepted October 27, 2015

Address for correspondence

Byoung-Joon Baek, MD, PhD

Department of Otolaryngology-

Head and Neck Surgery,

Cheonan Hospital,

Soonchunhyang University

College of Medicine,

31 Suncheonhyang 6-gil,

Dongnam-gu, Cheonan 31151, Korea

Tel $+82-41-570-2265$

Fax $+82-41-579-9022$

E-mail bjbaek@schmc.ac.kr
Background and Objectives The aim of this study was to analyse the radiological anatomic dimensions of the inferior turbinate in patients without deviated nasal septum and compare it to those in the patients with deviated nasal septum using computed tomography.

Subjects and Method The OMU CTs of 98 patients, 196 nostrils with or without deviated nasal septum were evaluated (control group: 42 patients, deviated septum group: 56 patients). The analysis of the CT scans contained the mucosal and bony length, mucosal width of the turbinate and the anterior and posterior mucosal overlay. And also evaluated the cross-sectional area and the type of inferior turbinate bone.

Results All subjects were divided into three groups: the concave, convex, and control groups. The correlations of fifteen measuring points such as anterior, middle and posterior medial mucosal thickness, total width, bone width, medial mucosa width of inferior turbinate, and area of inferior turbinate bone were significantly different among the groups (concave side $>$ control group $>$ convex side). Of the demographic factors, age was negatively correlated with mucosa and bone length. Types of inferior turbinate bone were as follows: lamella type (38\%), combined type $(37 \%)$, compact type $(25 \%)$.

Conclusion There were statistical differences in some measured anatomical points among the concave, convex, and control groups. Greater septum deviation was correlated with greater degree of hypertrophysm of the inferior turbinate. The age of patients showed negative correlation with inferior turbinate length. Most frequent type of inferior turbinate was lamella type. The results of this study may provide important information when considering turbinate surgery. Korean J Otorhinolaryngol-Head Neck Surg 2016;59(1):28-34

Key Words Computed tomography · Nasal septal deviation - Nasal septum · Turbinate.

\author{
서 론 \\ 비폐색을 주소로 이비인후과를 내원하는 환자에서, 이학적 \\ 검사시 비중격 만곡이 관찰되는 경우가 많다. 일반적으로 오목 \\ 한 비중격을 갖는 비강측의 경우 볼록한 비중격의 비강측에
}

비하여 좀 더 넓은 비강을 갖게 되어 비폐색이 덜할 것으로 생 각되지만 대부분의 환자는 양측의 비폐색을 호소하게 되며, 이학적 검사시에도 오목한 비강측 역시 좁은 비강이 관찰되 는 경우가 많다. 이는 비중격 만곡에 의한 보상성 비갑개 비후 (compensatory hypertrophy)의 기전에 의한 것으로, 보상성 비 
갑개 비후는 만곡으로 인한 공기역학적 불균형으로 기류의 양 이 많아지는 오목한 비중격을 갖는 비강의 건조 및 가피형성을 막기 위한 방어기전에 의해서 유발된다고 알려져 있다. 더욱이 이러한 현상은 양측 비강의 점액 섬모이동(mucociliary transport)에도 영향을 미쳐 비폐색을 더욱 심화시킬 수 있다. ${ }^{1-3)}$

이러한 비폐색의 원인이 되는 비중격의 만곡은 만곡의 정 도가 심하지 않은 경우, 약물치료를 통한 만곡 이외 염증질환 에 대하여 진단 및 약물치료를 먼저 시도하게 되고 이러한 약 물치료에 반응하지 않을 경우, 비중격 교정술(septoplasty)을 시도하게 된다. 비중격 교정과 더불어 변형된 하비갑개에 대 한 하비갑개 교정술을 동시에 적용할 수 있으나, 하비갑개 수 술의 적용 여부에 대하여는 논란의 여지가 있다. 이는 비중격 의 만곡이 비갑개의 비후 혹은 변형에 영향을 미치는지, 또 그 변형이 가역적인지에 대하여 다양한 결과를 갖는 연구들 이 존재하기 때문이다. ${ }^{4-11)} \mathrm{Ahn}$ 등 ${ }^{4)}$ 은 전산화단층촬영 영상 을 통하여 비중격 만곡과 하비갑개 후방부의 비후의 정도의 연관성에 대한 연구결과를 보고하였으며, $\mathrm{Kim}$ 등은 조직학 적 연구를 통하여 보상성 비갑개 비후가 발생되면, 하비갑개 점막상피에서 정상상피 박탈과 점막하 염증세포침윤이 증가 되고, 반대측에서는 점막하 선조직이 증가되는 것에 대하여 보고하였다. 또한 Myung 등은 비중격 만곡증에서 오목면 의 하비갑개 전방부와 중앙에서의 점막과 골부의 비후 및 내 측으로의 편위를 보고하였다. 하지만 이들 몇몇 연구의 경우, 연구대상의 수가 적거나 비중격 만곡과 비갑개 변형의 관계 를 연구하기 위한 측정된 해부학적 지표가 적거나 통계처리가 미흡한 단점이 있었다.

이러한 해부학적인 지표 간의 관계 분석 연구 이외에 성별 혹은 연령과 같은 임상적 인자와 측정점 간의 관계가 연구된 결과도 있으나, ${ }^{12,13)}$ 이들 연구 역시 측정된 지표가 적어 충분 한 의미 있는 결과를 얻기 어려운 부분이 있었다.

또한 여러 타국의 연구에서, 하비갑개의 형태학적 분석 및 분류에 대한 연구를 통하여 수술 전 임상적인 데이터를 얻고 자 하였으나, ${ }^{14)}$ 한국 인구에서의 형태학적 분류 연구는 없었다.

따라서 본 연구에서는 임상적으로 도움을 받기 위하여, 비중 격 만곡과 이에 대한 하비갑개의 변형에 대한 관계를 다양한 해부학적 지표와 만곡 사이의 관계 분석을 통하여 연구하였 으며, 이외에도 대상군 성별 및 나이 등의 임상적 인자와 하비 갑개의 관계 및 하비갑개의 형태에 대한 분류 연구를 하였다.

\section{대상 및 방법}

\section{대 상}

2012년 10월부터 2013년 12윌까지 비폐색을 주소로 본원
이비인후과를 내원하여 부비동 전산화단층촬영을 시행받은 성인 환자를 대상으로, 알레르기 비염, 각 부비동에 대한 LundMackay score상 1점을 넘는 부비동염 혹은 편측 부비동염, 비 중격 및 하비갑개를 제외한 비강 내의 해부학적인 변형이 있 거나, 안면부에 외상이 있었던 경우를 제외하고 총 98 명의 환 자, 196 개의 비공을 대상으로 하여, 이들을 비중격 만곡이 없는 대조군(control) 42명(M:F=26:16), 비공 84개와 비중격 이 만곡이 관찰되는 군 56 명( $\mathrm{M}: \mathrm{F}=36: 20)$, 비공 112 개를 다 시, 비중격이 만곡된 측의 볼록(convex)군, 및 비중격이 만 곡된 반대측의 오목(concave)군으로 나누어, 총 세 군에 대 한 해부학적 지표 사이의 통계분석을 하였다. 비중격 만곡의 정도는 볏돌기(crista galli)에서 전비극(anterior nasal spine) 이 이루는 직선을 기준으로 비중격이 이루는 각을 측정하여 $5^{\circ}$ 이상인 경우를 비중격 만곡으로 정의하였다. 대상 환자의 영상 획득 및 측정을 위하여 동은정보기술의 PACS, DEJAView 프로그램(Bucheon, Korea)을 이용하였으며, 모든 측정 은 한 명의 측정자를 통하여 수행되었다. 환자의 의료 정보는 본원 IRB 승인 후, 후향적으로 조사 연구하였다(SCHCA 201508-018).

\section{해부학적 지표}

전산화단층촬영 영상 분석을 통하여 볏돌기(crista galli) 에서 전비극(anterior nasal spine)이 이루는 직선을 기준으로 한 비중격 만곡의 각도(angle), 하비갑개 전단부에서 후단부 로의 해부학적 지표에 해당하는, 하비갑개의 총 전후방 점막 길이(mucosa length), 골부 길이(bone length)와 전산화단 층촬영 관상면 영상에서 하비갑개 점막의 전단부부터 하비 갑개 골부의 전단부까지의 길이에 해당하는 하비갑개 전방 점막 덮개 두께(anterior mucosal overlay), 하비갑개 골부의 후단부부터 하비갑개 점막의 후단부까지의 길이에 해당하는 하비갑개 후방 점막 덮개 두께(posterior mucosal overlay)에 대한 측정을 하였으며, 역시 관상면 영상 분석을 통하여, 하비 갑개의 골부가 시작되는 위치를 하비갑개의 전방(anterior), 부 비동 개구부(osteomeatal unit)가 가장 뚜렷한 위치를 중앙 (middle), 하비갑개의 골부가 끝나는 위치를 후방(posterior) 으로 지정한 후, 각각 하비갑개의 전방, 중앙, 후방에서 내측 에서 외측으로의 해부학적 지표에 해당하는 점막 두께(medial mucosal thickness)를 측정하였고, 역시 하비갑개 내측 에서 외측으로의 지표인 총 너비(total width), 골부 너비(bone width), 내측 점막 너비(medial mucosa width), 골부 면적 (area), 전방, 중앙, 하부 점막 두께(inferior mucosal thickness) 를 구하는 데 있어서는 부비동 개구부가 보이는 영상 중에서 구상돌기(uncinate process) 및 누두부(infundibulum)가 가 
장 두드러진 영상에서 측정하였다(Fig. 1).

전후방으로의 하비갑개 전체 길이 및 하비갑개 골부의 길 이의 경우, $1.2 \mathrm{~mm}$ 단면 두께의 전산화단층촬영 영상을 이 용하여, 이들 측정부위가 표현된 관상면 영상의 개수에 1.2 $\mathrm{mm}$ 를 곱하여 길이를 측정하였다. 이 연구에서의 중요한 지 표 중의 하나인 하비갑개의 내측 점막 두께의 경우 전방, 중 앙, 후방에서 측정되었으며, 좀 더 객관화된 내측 점막의 두께
를 산출하기 위해 각각의 위치에서 하비갑개의 최상부, 최하 부, 중간부에서 점막 두께를 측정하여 이에 대한 평균값으로 정의하였다. 하비갑개의 하부 점막 두께 역시 각각 전방, 중 앙, 후방에서 측정되었다(Fig. 1).

또한 이러한 하비갑개는 Uzun 등 ${ }^{14)}$ 이 하비갑개를 분류한 기준에 따라 판상형, 혼합형, 치밀형으로 분류하여 각각의 비율을 분석하였다(Fig. 2).
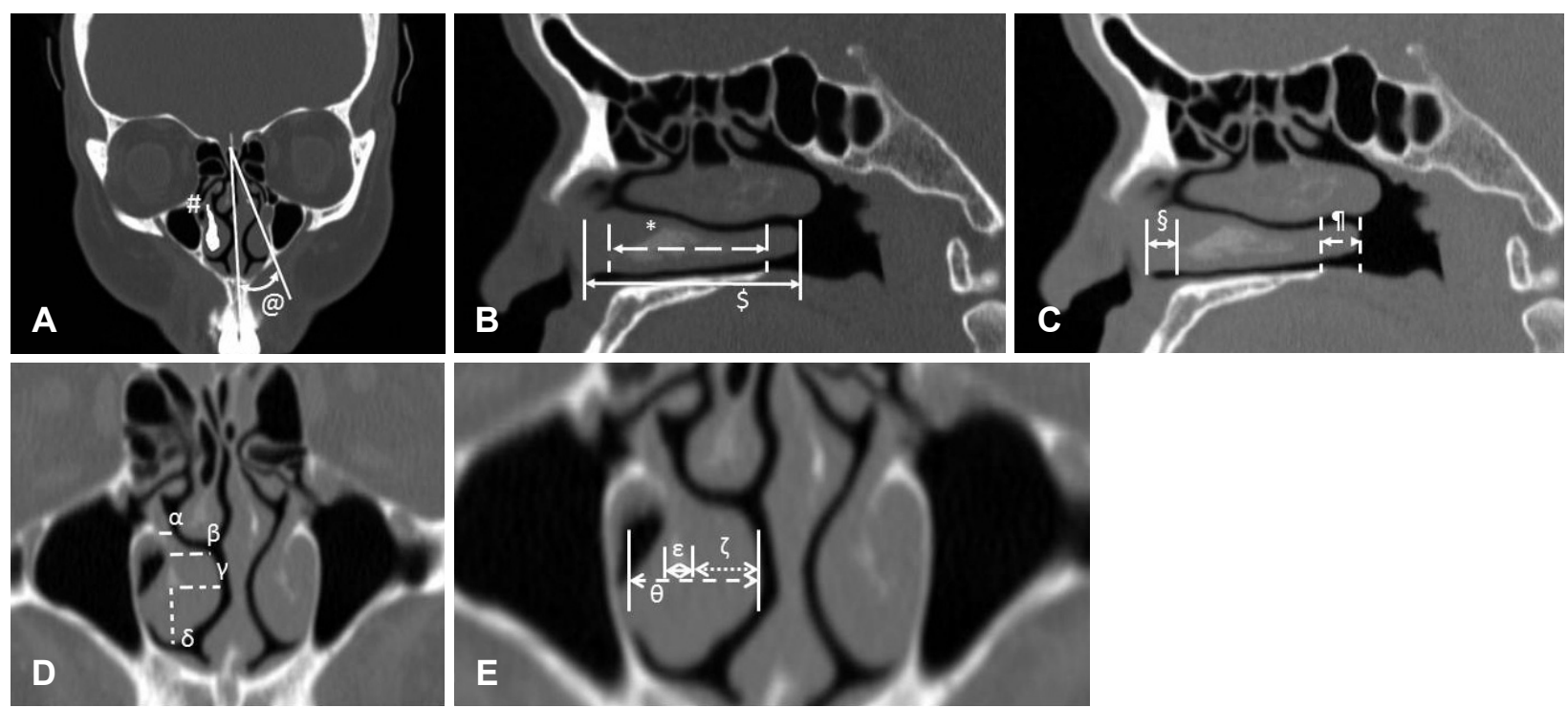

Fig. 1. Measuring point of septum and inferior turbinate. Septal angle (@), bone area (\#) (A). Mucosa length (\$), bone length $\left(^{*}\right)(B)$. Anterior mucosal overlay (§), posterior mucosal overlay (T) (C). Medial mucosal thickness (mean of $\alpha, \beta$, and $\gamma$ ), inferior mucosal thickness $(\delta)(D)$. Total width $(\theta)$, bone width $(\varepsilon)$, medial mucosa width $(\zeta)(E)$.
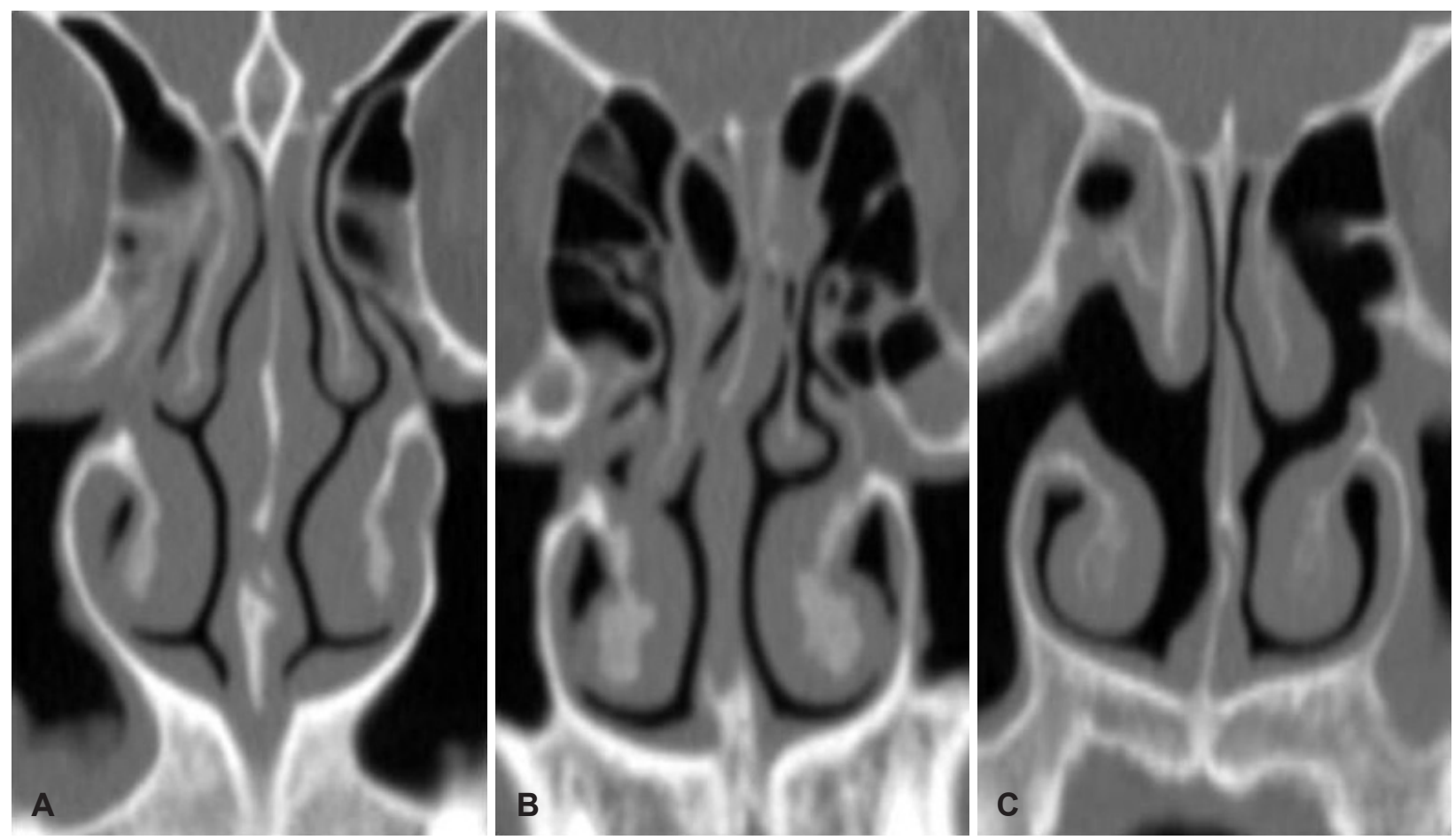

Fig. 2. Classifications of inferior turbinate type. Lamellar (A). Compact (B). Combined (C). 


\section{통 계}

대상군의 모든 인구통계학적 변수는 평균표준편차(means \pm standard deviation)로 표기하였다. 연구의 그룹 간 통계학적인 차이에 대한 분석을 위하여 one-way ANOVA, Tukey multiple comparisons 등의 방법을 이용하였으며, 나이와 측정된 측거점과의 관계분석을 위하여 Pearson's correlation test를 이용하였다. 모든 통계는 SPSS(18.0.0; SPSS Inc., Chicago, IL, USA)를 이용하여 분석되었으며, 통계학적 유의수준은 $5 \%$ 이내인 경우 통계학적으로 유의하다고 정의하였다.

\section{결 과}

본 연구에서는 비중격의 각도, 하비갑개 전후방 점막 전체 길이, 골부의 길이, 전방 점막 덮개 두께, 후방 점막 덮개 두께, 전방, 중앙, 후방 점막 두께, 하비갑개의 총 너비, 골부 너비, 내 측 점막 너비, 골부 면적, 전방, 중앙, 후방 하부 점막 두께 등 의 총 15 가지의 측정값과 이 측정값 간의 관계를 분석하였다.

대상 환자는 비중격 만곡이 없는 대조군 42 명 $(\mathrm{M}: \mathrm{F}=26: 16)$, 비공 84개와 비중격이 만곡이 관찰되는 군 56명 $(\mathrm{M}: \mathrm{F}=36: 20)$, 비공 112 개를 대상으로 하였으며, 평균 나이는 총 $43.18 \pm 17.6$, 각각 대조군 $40.76 \pm 16.56$, 비교군 $45 \pm 18.28$ 의 분포를 보였 다. 각각의 비공은 비중격 만곡의 정도에 따라 대조군, 오목 군, 볼록군 세 그룹으로 나누어 연구를 진행하였다.

먼저 총 대상 환자의 모든 비공을 대상으로 한 연구에서는,
여러 측정값과 이들 사이의 관계에서 상호 간의 다양한 상관 관계가 발견되었다. 이 중, 전후방 점막 전체 길이는 각각 골부 의 길이, 전방, 중앙, 후방 점막의 두께, 하비갑개의 총 너비, 골 부 너비, 골부 면적 등과 통계적으로 유의한 양의 상관관계를 보였다(r=0.55, 0.39, 0.17, 0.24, 0.28, 0.20, 0.23, $p<0.05)$.

또한 오목군, 볼록군, 대조군으로 그룹을 나누어 진행한 연구에서 각 군 간에 전방, 중앙, 후방 내측 점막 두께 및 총 너비, 골부 너비, 내측 점막 너비와 면적에서 세 군 간 통계학 적인 차이를 보였다. 이 내측 점막 두께는 전방, 중앙, 후방 모 두에서 세 그룹 간의 통계적으로 유의한 차이를 보였으며 $(p=$ $0.001,0.000,0.043)$, 전방, 중앙, 후방 모두에서 이 세 그룹의 내측 점막 두께는 오목면의 하비갑개 점막이 가장 두꺼웠고, 대조군, 볼록면의 하비갑개 점막순으로 볼록면의 하비갑개 점막이 가장 얇았다(Table 1).

관상면의 전산화단층촬영 이미지에서 구상돌기 및 누두부 가 가장 두드러진 부분에서 측정된 하비갑개의 총 너비, 점막 의 너비, 골부 너비 역시 세 그룹 간의 통계적으로 유의한 차 이를 보였으며, 내측 점막 두께와 마찬가지로 오목면에서 너 비가 가장 길었고 대조군, 볼록면의 순서를 보였으며 볼록면 에서의 너비가 가장 짧았다. 같은 관상면에서 하비갑개 골부 의 면적 역시 세 그룹 간의 통계학적으로 유의한 차이를 보였 다(Table 1). 하지만 이러한 통계학적인 차이(one-way ANOVA, Tukey multiple comparisons)와 더불어, 오목면에서는 중앙 내측 점막 두께와 하비갑개의 총 너비, 내측 점막 너비에서 비

Table 1. Comparisons among concave, convex, and control groups (one-way ANOVA, Tukey multiple comparisons)

\begin{tabular}{|c|c|c|c|c|c|c|c|}
\hline \multirow{2}{*}{ Variable mean } & \multicolumn{2}{|c|}{ Convex } & \multicolumn{2}{|c|}{ Concave } & \multicolumn{2}{|c|}{ Control } & \multirow{2}{*}{$p$-value } \\
\hline & Mean & Std Dev & Mean & Std Dev & Mean & Std Dev & \\
\hline Septal angle $\left(^{\circ}\right)$ & 8.89 & 2.70 & 8.89 & 2.70 & 2.01 & 2.08 & \\
\hline Mucosa length (mm) & 50.23 & 3.79 & 51.01 & 3.27 & 50.52 & 3.37 & 0.679 \\
\hline Bone length $(\mathrm{mm})$ & 36.00 & 2.71 & 35.93 & 2.68 & 36.10 & 2.62 & 0.639 \\
\hline \multicolumn{8}{|l|}{ Mucosal overlay (mm) } \\
\hline Anterior & 3.59 & 1.72 & 3.91 & 1.93 & 3.81 & 1.74 & 0.588 \\
\hline Posterior & 10.67 & 2.18 & 11.24 & 2.19 & 10.50 & 2.61 & 0.310 \\
\hline \multicolumn{8}{|l|}{ Medial mucosal thickness (mm) } \\
\hline Anterior* & 4.00 & 1.21 & 5.51 & 1.39 & 4.79 & 1.40 & $0.001^{*}$ \\
\hline Middle* & 3.51 & 0.88 & 4.88 & 1.34 & 4.13 & 1.16 & $0.000^{*}$ \\
\hline Posterior* & 6.03 & 1.50 & 7.00 & 1.63 & 6.87 & 1.40 & $0.043^{*}$ \\
\hline Total width $(\mathrm{mm})^{*}$ & 8.55 & 1.92 & 10.74 & 2.00 & 9.55 & 2.30 & $0.001^{*}$ \\
\hline Bone width $(\mathrm{mm})^{*}$ & 2.33 & 0.92 & 2.85 & 1.08 & 2.62 & 0.70 & $0.021^{*}$ \\
\hline Medial mucosa width* $(\mathrm{mm})^{*}$ & 3.63 & 1.05 & 4.89 & 1.36 & 4.17 & 1.22 & $0.025^{*}$ \\
\hline Bone area $\left(\mathrm{cm}^{2}\right)^{*}$ & 0.18 & 0.06 & 0.22 & 0.07 & 0.21 & 0.07 & $0.015^{*}$ \\
\hline \multicolumn{8}{|l|}{ Inferior mucosal thickness (mm) } \\
\hline Anterior & 3.24 & 1.09 & 3.72 & 1.13 & 3.66 & 1.28 & 0.779 \\
\hline Middle & 3.44 & 1.52 & 3.98 & 1.28 & 3.68 & 1.34 & 0.417 \\
\hline Posterior & 5.29 & 1.37 & 5.60 & 1.25 & 5.71 & 1.86 & 0.595 \\
\hline
\end{tabular}


중격 만곡의 정도가 만곡이 심해짐에 따라 중앙 내측 점막 두께와 하비갑개의 총 너비, 내측 점막 너비 측정값이 커지는 양의 상관관계(Pearson's correlation)를 보여주었으나, 이외 해부학적 지표와 반대 볼록면에서는 통계적으로 의미 있는 상관관계를 보여주지는 못했다(Table 2 and 3).

모든 하비갑개에 대한 측정값은 성별에 따른 통계적으로 유의한 차이를 보이지 않았으나, 연령의 경우 하비갑개 점막 및 골부의 길이와 연령이 증가함에 따라 측정값이 작아지는

Table 2. Correlation of septal angle and other anatomical points (concave side)

\begin{tabular}{lcc}
\hline & \multicolumn{2}{c}{ Septal angle } \\
\cline { 2 - 3 } & $\mathrm{r}$ & $\mathrm{p}$ \\
\hline Mucosal length & 0.04 & 0.79 \\
Bone length & -0.17 & 0.22 \\
Mucosal overlay & & \\
$\quad$ Anterior & 0.06 & 0.68 \\
$\quad$ Posterior & 0.17 & 0.20 \\
Medial mucosal thickness & & \\
$\quad$ Anterior & 0.10 & 0.46 \\
$\quad$ Middle & $0.29^{*}$ & $0.03^{*}$ \\
$\quad$ Posterior & 0.12 & 0.37 \\
Total width & $0.28^{*}$ & $0.04^{*}$ \\
Bone width & 0.14 & 0.32 \\
Medial mucosal width & $0.29^{*}$ & $0.03^{*}$ \\
Bone area & -0.04 & 0.77 \\
Inferior mucosal thickness & & \\
Anterior & 0.22 & 0.10 \\
Middle & 0.21 & 0.12 \\
Posterior & 0.15 & 0.28 \\
\hline
\end{tabular}

$* p<0.05$
음의 상관관계를 보였으며, 각각 하비갑개 점막 길이는 $r=-0.22$, $p=0.002$ 골부의 길이는 $\mathrm{r}=-0.15, p=0.038$ 의 결과값을 보여 주었다(Fig. 3). Uzun 등 ${ }^{9}$ 이 발표한 터키인구에서의 하비갑 개 분류에 따르면 순서대로 치밀형, 판상형, 혼합형의 순서로 높은 비율을 보였으나, 한국인을 대상으로 한 본 연구의 경 우, 판상형(38\%), 혼합형(37\%), 치밀형(25\%)의 순으로 높은 비율을 보였으며, 각각의 분류에서 대조군, 오목군, 볼록군이 속한 수와 각각의 그룹에서의 비율은 판상형에서는 볼록군

Table 3. Correlation of angle and other anatomical points (convex side)

\begin{tabular}{lcc}
\hline & \multicolumn{2}{c}{ Septal angle } \\
\cline { 2 - 3 } & $r$ & $p$ \\
\hline Mucosal length & -0.02 & 0.86 \\
Bone length & -0.17 & 0.22 \\
Mucosal overlay & & \\
$\quad$ Anterior & 0.04 & 0.76 \\
$\quad$ Posterior & 0.02 & 0.87 \\
Medial mucosal thickness & & \\
$\quad$ Anterior & -0.17 & 0.21 \\
$\quad$ Middle & 0.00 & 0.98 \\
$\quad$ Posterior & -0.07 & 0.60 \\
Total width & -0.06 & 0.66 \\
Bone width & -0.07 & 0.63 \\
Medial mucosal width & 0.05 & 0.74 \\
Bone area & -0.14 & 0.30 \\
Inferior mucosal thickness & & \\
$\quad$ Anterior & 0.00 & 0.99 \\
Middle & -0.08 & 0.57 \\
Posterior & 0.07 & 0.62 \\
\hline * $<0.05$ & & \\
& &
\end{tabular}

Fig. 3. Correlation between $(A)$ age and mucosa $(B)$, bone length. Age was negative correlated with mucosa $(r=-0.22, p=0.002)$ and bone length $(r=-0.15, p=0.038)$. 
Radiologic Evaluation of the Inferior Turbinate I Park DY, et al.

Table 4. Turbinate type and distribution of deviation group

\begin{tabular}{|c|c|c|c|c|c|}
\hline \multicolumn{3}{|c|}{ Type of inferior turbinate } & \multicolumn{3}{|c|}{ Deviation group distribution } \\
\hline Type & $n$ & $\%$ & Group & $\mathrm{n}$ & $\%$ of each groups (straight, concave, convex) \\
\hline \multirow[t]{3}{*}{ Lamella } & 75 & 38 & Straight $(n=84)$ & 29 & 34.5 \\
\hline & & & Concave $(n=56)$ & 21 & 37.5 \\
\hline & & & Convex $(n=56)$ & 25 & 44.6 \\
\hline \multirow[t]{3}{*}{ Compact } & 49 & 25 & Straight & 27 & 32.1 \\
\hline & & & Concave & 12 & 21.4 \\
\hline & & & Convex & 10 & 12.9 \\
\hline \multirow[t]{3}{*}{ Combined } & 72 & 37 & Straight & 28 & 33.3 \\
\hline & & & Concave & 23 & 41.1 \\
\hline & & & Convex & 21 & 37.5 \\
\hline
\end{tabular}

(44.6\%)에서 오목군(37.5\%)에 비하여 총 볼록군 대비 좀 더 높은 비율로 판상형에 속하였으며, 치밀형에서는 오목군 (21.4\%)에서 볼록군(12.9\%)에 비하여 총 오목군 대비 좀 더 높은 비율로 치밀형에 속하였다(Table 4).

\section{고 찰}

비중격 만곡증은 비폐색으로 이비인후과를 내원하는 많 은 수의 환자에서 관찰되는 비교적 흔한 질환이다. 이러한 비 중격 만곡이 환자의 비폐색, 비두통 등의 증상을 설명할 수 있을 정도로 만곡의 정도가 심하거나, 기타 가능한 원인이 발견되지 않을 때 비중격에 대한 수술적 처치를 고려하게 된 다. 이러한 비중격의 수술적 처치와 더불어 비폐색을 더욱 효 과적으로 해결하기 위해 하비갑개에 대한 수술적 처치를 고 려하게 되는데, 이러한 처치를 고려하기 위해서는 비중격의 만 곡이 하비갑개의 변형에 기여를 하는지, 또 하비갑개의 변형에 기여를 한다면 하비갑개의 어떤 부위에 가장 큰 기여를 하는 지에 대한 연구가 선행되어야 한다. 또한 이러한 하비갑개의 변형이 성별에 따라 달리 나타나지는 않는지, 연령에 따른 차 이점이 없는지에 대한 고려가 있어야 하비갑개에 대한 처치 시에 술자가 결정해야 할 절제 축소의 범위에 계획을 세울 수 있다. 또한 술기 전에 하비갑개의 분류에 대한 정보가 있 다면 이 역시도 술기 시에 효과적인 사전 정보가 될 수 있다. 본 연구는 이러한 필요성 하에서 수행되었으며 총 15 가지의 측정값과 이 측정값 간의 관계를 분석하였다.

먼저 총 환자의 비공을 대상으로 한, 여러 측정값과 측정 값 사이의 관계 중에서 전후방 점막 전체 길이는 골부의 길이, 전방, 중앙, 후방 점막의 두께, 하비갑개의 총 너비, 골부 너비, 골부 면적 등과 통계적으로 유의한 양의 상관관계를 보였는 데 이는 전후방의 점막 측정값이 전후방의 한 방향으로 국한 된 것이 아닌, 전후방, 내외측으로의 모든 방향으로의 변형에 영향을 미칠 가능성이 높은 것으로 추정하였다. 하지만 이들
상관 관계지수가 통계적 유의성을 갖기는 하였으나, 비교적 높 지 않아 연구의 제한점으로 작용할 수 있을 것으로 생각된다.

또한 오목군, 볼록군, 대조군의 세 군 간에 전방, 중앙, 후방 내측 점막 두께 및 총 너비, 골부 너비, 내측 점막 너비와 면적 에서 유의한 차이를 보였는데, 이 세 그룹 간의 두께 혹은 너비 의 차이는 모두 오목면의 하비갑개에서 가장 두껍거나 길었 고, 볼록면에서 가장 얇거나 짧았다. 이는 비중격의 만곡이 오목한 면에서 하비갑개의 여러 측거점에 부종이나 과성장 등의 병적 기전을 촉발하여 비폐색을 일으킬 수 있음을 의미 하며, 반대로 볼록면에서는 위축 혹은 성장저하를 일으킨다 고 생각할 수 있다. 또한 이러한 세 군 간의 유의한 통계학적 인 차이와 더불어, 오목면의 중앙 내측 점막 두께와 하비갑 개의 총 너비, 내측 점막 너비에서는 비중격 만곡의 정도가 심해짐에 따라 하비갑개 변형이 커지는 선형의 상관관계를 보였다.

$\mathrm{Ahn}$ 등 ${ }^{4}$ 은 전산화단층촬영 영상을 통하여 비중격 만곡 이 관찰되는 대상에서 하비갑개의 외측 점막에 비해 내측 점 막의 비후가 관찰되며, 이에 대한 연구를 통하여 비중격과 하비갑개에 대한 관계를 서술하였으나, 대조군이 없고, 적은 대상군 및 비갑개에서의 측정점 간의 관계에 대한 연구가 부 족하였다. 또한 Myung 등은 비중격 만곡이 관찰되는 환자 를 대상으로 오목면 하비갑개에서 점막과 골부의 비후 등이 관찰되는 연구를 발표하였으나, 하비갑개의 측정점 간의 관 계에 대한 연구가 부족하였다. 본 연구는 지금까지 연구된 모 든 지표를 포함하여 가장 많은 해부학적 지표에 대하여 연구 하였으며 더불어 이들 측정점 간의 관계에 대한 통계적 분석 을 추가하였다.

또한 본 연구에서는 성별 및 연령 등의 임상적 요소와 하비 갑개의 해부학적 지표에 대한 연구를 추가로 수행하였다. 하비 갑개의 변형은 성별과 통계적으로 유의한 관계를 보이지 않 았으나, 연령의 경우 전후방으로의 하비갑개 점막 및 골부의 길이가 연령이 증가함에 따라 감소하는 음의 상관관계를 보 
였다. 비록 상관관계 계수가 크지는 않으나, 골부의 길이('r)보 다 점막의 길이(r)에서 좀 더 강한 음의 상관관계 계수를 보였 으며 $\left(\mathrm{r}=-0.22>\mathrm{r}^{\prime}=-0.15\right)$, 연령이 증가함에 따라 하비갑개가 전후방으로 위축되는 경향을 보이는 것으로, 젊은 환자의 경 우에서 과도한 하비갑개 절제술이 수행될 경우에 그 환자가 연령이 증가함에 따라 위축성 비염의 소견을 보일 수 있는 것으로 해석 될 수 있다. San 등히은 연구를 통하여, 연령이 증가함에 따라 혈관 및 분비샘 구조 변형으로 인한 비중격의 변형 및 위축하는 경향이 있음을 보고하였다. 본 연구에서는 하비갑개 역시 비중격의 경우처럼 연령에 따라 변형될 수 있 음을 분석한 것으로, 음의 상관관계를 보이기는 하였으나 비 폐색 증상이 있는 환자를 대상으로 하여 일반적으로 적용되 기 어려울 수 있고, 비주기(nasal cycle)에 따라 비강의 점막이 좌우 교대로 팽창 또는 수축할 수 있음을 고려할 때, 이러한 인자가 연구의 한계로 분석되지 못하여 제한점으로 작용할 수 있으며, 또 높은 상관관계 계수를 보이지는 않았기 때문 에 해석에 제한이 있을 수 있으며 추후, 비증상이 없는 일반 대상을 포함하는 많은 대상군 수를 바탕으로 병리학적인 소 견을 추가하여 좀 더 구체적인 연구를 수행할 예정이다.

Uzun 등 ${ }^{14}$ 은 연구를 통하여 터키인구에서의 그들의 하비 갑개 분류법에 따라 높은 비율의 순서대로 치밀형, 판상형, 혼합형을 보인다고 발표하였으나, 본 연구의 경우 판상형이 가장 높은 비율을 보였다. 또한 본 연구의 비중격과 하비갑 개 간의 형태학적 연구 결과와 유사하게, 판상형에서는 볼록 군이 치밀형에서는 오목군이 각 그룹의 총합 대비 높은 비율 로, 각각 판상형, 치밀형에 속하였다. 비록 대상군이 인구통 계학적인 측면에서 분석되기에는 수가 많지 않으나, 이는 하 비갑개에 대한 술기의 측면에서 치밀형의 경우, 하비갑개 조 작이 어렵고 골부의 두께가 두꺼워 절제술이 필요한 데 반해 판상형의 경우, 하비갑개 조작이 비교적 쉬운 형태로, 골부에 대한 절제보다는 점막의 위축을 유도하는 시술이나, 하비갑 개의 외측 골절을 이용하여 처치 가능한 경우가 많을 수 있다.

\section{REFERENCES}

1) Joe SA, Patel S. Nonallergic rhinitis. In: Flint PW, Haughey BH,
Lund VJ, Niparko JK, Richardson MA, Robbins KT, Thomas JR, editors. Cummings Otolaryngology-Head and Neck Surgery. 5th ed. Philadelphia: Elsevier;2010. p.694-702.

2) Myung NS, Park BS, Lee HJ, Koo SK, Roh HJ. Analysis of structural changes of the inferior turbinate in patients with deviated nasal septum by using computed tomography. Korean J OtorhinolaryngolHead Neck Surg 2008;51(12):1104-8.

3) Kim SW, Park HJ, Jun BC, Ahn KJ, Lee SK, Kim SW, et al. Nasal septal deviation and compensated inferior turbinate hypertrophy. Korean J Otolaryngol-Head Neck Surg 2005;48(1):46-50.

4) Ahn BH, Lee SY, Sohn SG, Shin HC, Kim ED, Nam SI. The relationship between nasal septal deviation and inferior turbinate hypertrophy. Korean J Otolaryngol-Head Neck Surg 2003;46(11): 950-4.

5) Kim BH, Ryu JM, Cho YC, Lim DJ, Lee BY. Histopathology of the inferior turbinate showing compensatory hypertrophy in patients with deviated nasal septum. Korean J Otolaryngol-Head Neck Surg 2003;46(3):230-3.

6) Egeli E, Demirci L, Yazýcý B, Harputluoglu U. Evaluation of the inferior turbinate in patients with deviated nasal septum by using computed tomography. Laryngoscope 2004;114(1):113-7.

7) Berger G, Hammel I, Berger R, Avraham S, Ophir D. Histopathology of the inferior turbinate with compensatory hypertrophy in patients with deviated nasal septum. Laryngoscope 2000;110(12):2100-5.

8) Lee TH, Kim BY, Kim DY. Effectiveness of the turbinoplasty in the patient with deviated septum of nose. Korean J Otolaryngol 2005;48(3):326-31.

9) Uzun L, Savranlar A, Beder LB, Ugur MB, Cinar F, Ozdemir H, et al. Enlargement of the bone component in different parts of compensatorily hypertrophied inferior turbinate. Am J Rhinol 2004; 18(6):405-10.

10) Orhan I, Aydın S, Ormeci T, Yılmaz F. A radiological analysis of inferior turbinate in patients with deviated nasal septum by using computed tomography. Am J Rhinol Allergy 2014;28(1):e68-72.

11) Akoğlu E, Karazincir S, Balci A, Okuyucu S, Sumbas H, Dağli AS. Evaluation of the turbinate hypertrophy by computed tomography in patients with deviated nasal septum. Otolaryngol Head Neck Surg 2007;136(3):380-4.

12) Samoliński BK, Grzanka A, Gotlib T. Changes in nasal cavity dimensions in children and adults by gender and age. Laryngoscope 2007;117(8):1429-33.

13) San T, Muluk NB, Saylisoy S, Acar M, Cingi C. Nasal septal body and inferior turbinate sizes differ in subjects grouped by sex and age. Rhinology 2014;52(3):231-7.

14) Uzun L, Ugur MB, Savranlar A, Mahmutyazicioglu K, Ozdemir H, Beder LB. Classification of the inferior turbinate bones: a computed tomography study. Eur J Radiol 2004;51(3):241-5. 